\title{
Advanced metering in buildings: strategies for increasing its use
}

\author{
Medición avanzada en los edificios: estrategias para el aumento de su uso
}

\author{
Marina S. de Oliveira Ilha ${ }^{1} \quad$ Jorge Venâncio de Freitas Monteiro ${ }^{1}$ \\ Recibido 3 de enero de 2014, aceptado 20 de junio de 2014 \\ Received: January 3, 2014 Accepted: June 20, 2014
}

\begin{abstract}
Implementation of advanced metering of gas and water consumption is an ongoing challenge in some developing countries. After a review of the literature, five strategies of advanced metering that could be implemented for increasing the use of advanced metering were identified, considering Brazil as a case study: transfer of the ownership of metering instruments from utilities to other users, establishment of a metering service provider, development of a metering systems inspection agent, use of prepaid systems operated by condominiums and methods for data transmission for on-site remote meter reading. To assess the feasibility of each strategy, fourteen experts from utility companies and companies involved in the implementation of remote and individual metering systems were interviewed. After a content analysis and validation of the experts' responses, strategies for implementing advanced utility metering were proposed, that entail relatively simple actions that may be accomplished by local players involved directly in metering activities.
\end{abstract}

Keywords: Advanced metering, water metering, gas metering, sub-metering.

\section{RESUMEN}

Implementación de medición avanzada del consumo de gas y de agua es un desafío permanente en algunos países en desarrollo. Después de una revisión de la literatura, se identificaron cinco estrategias de medición avanzada que se podrían implementar para aumentar el uso de la medición avanzada, considerando a Brasil como un estudio de caso: la transferencia de la propiedad de los instrumentos de medición de los servicios públicos para los demás usuarios, creación de un proveedor de servicios de medición, el desarrollo de un agente de la inspección de los sistemas de medición, el uso de sistemas de prepago operados por condominios e implementar métodos para la transmisión de datos de las instalaciones a través de lectura remota de medidores. Para evaluar la viabilidad de cada estrategia, se entrevistó a catorce expertos de las empresas de servicios públicos y las empresas que participan en la implementación de sistemas de medición remotos e individuales. Después de un análisis de contenido y la validación de las respuestas de los expertos, se propone estrategias para la implementación de la medición avanzada que impliquen acciones relativamente simples y que pueden ser realizadas por los agentes locales que están participando directamente en las actividades de medición.

Palabras clave: Medición avanzada, medidores de agua, medición de gas, sub-medición.

\section{INTRODUCTION}

The term advanced metering has been used for any metering system that replaces manual reading by remote communication. For this purpose, this systems contemplates advanced meters, which are equipments that measure and record usage data at hourly intervals or more frequently, and

\footnotetext{
1 Faculdade de Engenharia Civil, Arquitetura e Urbanismo. Universidade Estadual de Campinas. Av. Albert Einstein, 951 13083852. Campinas, São Paulo, Brasil. E-mail: milha@fec.unicamp.br; venanciocomgas@uol.com.br
} 
provide usage data to both consumers and energy companies at least once daily. Data are used for billing and other purposes. Advanced meters include basic hourly interval meters, meters with one-way communication, and real time meters with built-in two-way communication capable of recording and transmitting instantaneous data [1].

The concept of advanced metering incorporates consumption management on the demand side and energy and water conservation programs. Advanced metering leads to increased operational efficiency, improved customer service, enhanced distribution reliability and greater revenue assurance [2].

A worldwide change in technological paradigms in utility metering methods has resulted from recent advances in computer systems and telecommunications. Individual metering using advanced metering infrastructure (AMI) is already mandatory in many countries [3]. In Brazil, however, the use of AMI techniques are driven by local market forces. Implementation of these systems might be an opportunity to reduce waste because end users will pay for what they consume rather than a fixed percentage of the consumption by the entire building in which they live.

In addition, the substantial transformations that are taking place in water, power and gas companies are not restricted to technical innovations. A new economic era is beginning in which considerable efficiency gains can be achieved through reorganizing all the supporting players in this market, resulting in new business practices, including those whose principal focus is utility metering.

The economies of scale and scope in electricity, water and gas utilities were explored by [4] and the author concluded that, even after accounting for unobserved heterogeneity, scope economics exists in the majority of multi-utilities and that, for small companies in particular, the savings associated with scope economies are considerable.

The combination of the services of utility companies, when properly planned, results in a series of benefits such as economies of scale and scope, as well as the opportunity to implement new technologies such as advanced metering [5]. In many countries, the use of these technologies has been encouraged by government agencies because of the various benefits to society and the possibility of efficiency gains [6].

The US government, for example, has shown interest in transferring the costs of utility services to the population in general, principally in locations where there are environmental incentives for rationalization of consumption, i.e., a "green effect." New metering technologies permit the introduction of "read-bill-collect" processes, which essentially involve companies providing metering services [7].

Another typical example is the introduction of multi-utilities that combine the services of various utility companies (such as water, power and gas) in a unified structure in order to perform their operational activities together, thus obtaining economies of scope and scale and consequent efficiency gains [8]. The introduction of competitiveness in activities related to metering instruments is fundamental to ensuring the interests of consumers and encouraging technological innovations in metering, such as remote reading, prepayment systems and cost reduction [9].

In US, England and other countries, interactions among the technological, economic, political and regulatory aspects of the services rendered by utility companies have been taken into account in the implementation of advanced metering systems [10].

The conventional belief is that the market can function with only a buyer and a seller, but this is no longer considered sufficient [11] the market also needs favorable and consistent policies and regulatory frameworks, institutional support, infrastructure and services [12-14].

Introduction of new technologies is necessarily a social and cultural transformation that implies adaptation to a new context [15]. The implementation of advanced metering in an efficient manner is still a challenge in some developing countries, like Brazil, principally because both the companies that provide utility services and those that supply and install remote metering systems in buildings have appeared in an unplanned manner, in most cases in response to demand from construction companies or condominiums. In other words, the market is not regulated or standardized. 
In European countries and in the United States, one of the market forces that have led to the use of advanced metering systems is the high cost of reading meters. For example, in Connecticut, costs of approximately US $\$ 2.30$ per reading were cited as the motivation for implementing a radio metering system in the 1980s [16]. It was not find systematic study of this cost in other countries; in Brazil, for example it is approximately US $\$ 0.17$ per reading.

In Brazil, the main factor prompting implementation of individual consumption metering systems in condominiums has been social pressure from residents of condominium of apartments who claimed for a fair water and gas billing. The urban and architectural features of large metropolises, combined with market forces favouring individual metering, have already led to a demand for remote metering in residential buildings, even without government incentive.

Construction companies usually deliver the new house apartments with collective metering, as individual metering is not mandatory. After the occupancy of the buildings, the condominiums claims for individualization, and most of them installed on site remote meter reading systems (OMR). A cost effectiveness analysis was performed in a typical medium class multifamily building with: (a) all individual meters located at the ground floor and (b) individual meters located at the several floors, with remote metering [17]. The savings were about $35 \%$ when meters were not centralized.

Despite the enormous potential for advanced metering in the country, no implementation and management model has yet been defined. Brazil, as other developing countries has characteristics that differ considerably from those of the countries in which most advanced metering technologies have been established. Because of these characteristics, it might not be feasible to simply implement a technology imported from abroad.

This paper identifies strategies to increase the use of advanced metering systems according to a management point of view.

\section{METHOD}

First, it was undertaken a broad search of the national and international literature to identify technological and administrative issues associated with advanced metering.

The premise was prioritization of advanced metering strategies that have potential for implementation from the user's perspective, which could be used at an early stage of regulation of utility companies and where the use of advanced metering is essentially limited to remote metering managed by condominiums.

Five categories of AMI were selected for the next stage of the analysis: (1) transfer of ownership of metering instruments from utilities to other players, (2) establishment of metering service providers, (3) development of metering systems inspection agents, (4) use of prepaid systems operated by condominiums and (5) types of data transmission for on-site remote meter reading.

Afterwards, professionals from two groups were interviewed: (1) experts of utility companies and (2) executives of companies involved in implementation of remote and individual metering systems. Theoretical sampling was used for the selection of the respondents.

The interview's guide contains open-ended questions, where the respondent freely exposed their ideas, questions controlled by the theory and directly related to the research topics, and confrontational questions to review exposed concepts.

To help ensure the reliability of the research, two techniques were used in the interviews: including more than one question addressing the same topic and checking the consistency of responses within the same group of professionals. Data were collected by audio recording.

Each interview was transcribed and validated by the respondent by means of a Content Analysis [18], in which the results of the interview were presented in graphical (disposition content techniques) form in a second meeting. The data were then expressed as concepts and relationships among them are established in order to formulate conclusions [19]. The validation the results obtained was performed by the following tools:

- cross-examination using data from the two groups of respondents; 
- equivalence of concepts expressed by a respondent through the formulation of contradictory questions;

- stability of the consistence of the answers through comparison between the two groups of respondents and the literature review.

After that, axial and selective codification were carried out. For doing it, each category was divided in several subcategories for better understanding the reasons of the initial position stated by the respondent and get achievements to perform the selective codification. For that, each response was classified in Acceptable or Problematic.

\section{RESULTS AND DISCUSSION}

The sample comprised experts from the majority of the players involved with this Issue at the most important Brazilian region and contemplated fourteen professionals, seven from utility companies (UC) and seven from metering systems implementation companies (OE). All the respondents had worked for more than ten years in the field.

Tables 1, 2, 3 and 4 show the results of the axial codification of the professional's opinions for each category investigated in this study. Table 5 shows the final result of open codification of responses, by category and group of professionals.

The results obtained by the codification process may be summarized as follows:

- The change transferring ownership of gas and water meters from utilities to other players would not be feasible in the short term, but this assertion does not apply to remote meter reading systems or advanced metering technologies.

Table 1. Axial codification of the responses for the category: Transfer of ownership of metering instruments from utilities companies to other players. Grey cells indicate the respondent agrees with the opinion (O) about the sub-category.

\begin{tabular}{|c|c|c|c|c|c|c|c|c|c|c|c|c|c|c|}
\hline \multirow{2}{*}{\multicolumn{2}{|c|}{ Sub-category }} & \multirow{3}{*}{$\begin{array}{c}\mathbf{O} \\
\mathrm{P}\end{array}$} & \multicolumn{12}{|c|}{ Respondent } \\
\hline & & & \multirow[t]{2}{*}{\begin{tabular}{|l|l|l|}
$\mathbf{A 1}$ & $\mathbf{A 2}$ & $\mathbf{H}$ \\
\end{tabular}} & \multirow[t]{2}{*}{ B1| } & \multirow[t]{2}{*}{\begin{tabular}{|l|l|l|} 
B2 & 1 \\
\end{tabular}} & \multirow{2}{*}{\multicolumn{2}{|c|}{\begin{tabular}{|l|l|} 
B3 & $\mathbf{C}$ \\
\end{tabular}}} & \multirow[t]{2}{*}{\begin{tabular}{l|l|l|l|} 
& $\mathbf{C} 2$ & 1 \\
\end{tabular}} & \multirow[t]{2}{*}{\begin{tabular}{|l|l|l|} 
D1 & \\
\end{tabular}} & \multirow[t]{2}{*}{22} & \multirow{2}{*}{\multicolumn{2}{|c|}{\begin{tabular}{|l|l|} 
D3 & E1 \\
\end{tabular}}} & \multirow{2}{*}{\multicolumn{2}{|c|}{\begin{tabular}{|l|l|l|} 
E2 & F1 & G1 \\
\end{tabular}}} \\
\hline $\begin{array}{l}\text { Metering transparency and } \\
\text { acceptance by users }\end{array}$ & $\frac{\mathscr{a}}{\mathrm{r}}$ & & & & & & & & & & & & & \\
\hline Cost-effectiveness feasibility & 焉 & $\mathrm{N}$ & & & & & & & & & & & & \\
\hline Tampering & $\sum$ & $\mathrm{P}$ & & & & & & & & & & & & \\
\hline Technical support & 될 & $\mathrm{P}$ & & & & & & & & & & & & \\
\hline Scale economy & 尝 & $\mathrm{P}$ & & & & & & & & & & & & \\
\hline Quality control & $\sqrt{3}$ & $\mathrm{P}$ & & & & & & & & & & & & \\
\hline Warranty & $\bar{z}$ & $\mathrm{P}$ & & & & & & & & & & & & \\
\hline Regulation/ technical standards & & $\mathrm{P}$ & & & & & & & & & & & & \\
\hline $\begin{array}{l}\text { Metering transparency and } \\
\text { acceptance by users }\end{array}$ & & $A^{*}$ & & & & & & & & & & & & \\
\hline Cost-effectiveness feasibility & 至 & A & & & & & & & & & & & & \\
\hline Tampering & $\sum$ & $\mathrm{A}^{*}$ & & & & & & & & & & & & \\
\hline Technical support & 될 돕 & $\mathrm{P}$ & & & & & & & & & & & & \\
\hline Scale economy & $\sum_{i=1} \sum_{i}$ & A & & & & & & & & & & & & \\
\hline Quality control & is & $\mathrm{P}$ & & & & & & & & & & & & \\
\hline Warranty & $\sum_{i}^{e}$ & $\mathrm{P}$ & & & & & & & & & & & & \\
\hline $\begin{array}{l}\text { Regulation and technical } \\
\text { standards }\end{array}$ & $\frac{-1}{\alpha}$ & $\mathrm{P}$ & & & & & & & & & & & & \\
\hline
\end{tabular}

A, B, C .. G - companies 1,2,3 - professionals $\mathrm{O}$ - Opinion $\mathrm{P}$ - problematic $\mathrm{A}$ - acceptable $\mathrm{N}$ - not confirmed $\mathrm{A}^{*}$ - acceptable, if bulk meter exists. 
Table 2. Axial codification of the responses for the category: Establishment of metering service providers. Grey cells indicate the respondent agrees with the opinion $(\mathrm{O})$ about the sub-category.

\begin{tabular}{|c|c|c|c|c|c|c|c|c|c|c|c|}
\hline \multirow{2}{*}{ Sub-category } & \multirow{2}{*}{ O } & \multicolumn{10}{|c|}{ Respondent } \\
\hline & & \begin{tabular}{l|l|}
$\mathbf{A 1}$ & $\mathbf{A 2}$ \\
\end{tabular} & B1 & B2 & \begin{tabular}{|l|l|} 
B3 & C1 \\
\end{tabular} & C2 & D1 & D2 & \begin{tabular}{|l|l|} 
D3 E1 \\
\end{tabular} & \begin{tabular}{|l|l|} 
E2 & I
\end{tabular} & \begin{tabular}{l|l|} 
F1 & G1 \\
\end{tabular} \\
\hline Quality of services & $\mathrm{P}$ & & & & & & & & & & \\
\hline Regulation/ technical standards & $\mathrm{P}$ & & & & & & & & & & \\
\hline Supervision of services & $\mathrm{P}$ & & & & & & & & & & \\
\hline Cost-effectiveness feasibility & A & & & & & & & & & & \\
\hline Regulation of business-related services & $\mathrm{P}$ & & & & & & & & & & \\
\hline $\begin{array}{l}\text { Consumption suppression and interface with } \\
\text { utilities companies }\end{array}$ & $\mathrm{P}$ & & & & & & & & & & \\
\hline
\end{tabular}

A, B, C .. G - companies 1,2,3 - professionals $\mathrm{O}$ - Opinion $\mathrm{P}$ - problematic $\mathrm{A}$ - acceptable.

Table 3. Axial codification of the responses for the category: Development of metering system inspection agents. Grey cells indicate the respondent agrees with the opinion $(\mathrm{O})$ about the sub-category.

\begin{tabular}{|l|l|l|l|l|l|l|l|l|l|l|l|l|l|l|l|l|}
\hline \multicolumn{1}{|c|}{ Sub-category } & O & \multicolumn{7}{c|}{ Respondent } \\
\hline Market demand & A1 & A2 & B1 & B2 & B3 & C1 & C2 & D1 & D2 & D3 & E1 & E2 & F1 & G1 \\
\hline Economic feasibility & P & & & & & & & & & & & & & & \\
\hline Quality of services & P & & & & & & & & & & & & & & \\
\hline $\begin{array}{l}\text { Conflict with activities inherent to legal } \\
\text { metrological supervision }\end{array}$ & P & & & & & & & & & & & & & & \\
\hline
\end{tabular}

A, B, C ... G - companies 1,2,3 - professionals $\mathrm{O}$ - Opinion $\mathrm{P}$ - problematic $\mathrm{A}$ - acceptable.

Table 4. Axial codification of the responses for the category: Use of prepaid systems operated by condominiums. Grey cells indicate the respondent agrees with the opinion $(\mathrm{O})$ about the subcategory.

\begin{tabular}{|l|l|l|l|l|l|l|l|l|l|l|l|l|l|l|l|}
\hline \multicolumn{1}{|c|}{ Sub-category } & \multirow{2}{*}{$\mathrm{O}$} & \multicolumn{8}{|c|}{ Respondent } \\
\hline & & A1 & A2 & B1 & B2 & B3 & C1 & C2 & D1 & D2 & D3 & E1 & E2 & F1 & G1 \\
\hline Operation, maintenance, technical assistance & P & & & & & & & & & & & & & & \\
\hline Cost-effectiveness feasibility & $\mathrm{P}$ & & & & & & & & & & & & & & \\
\hline Legal operation & $\mathrm{P}$ & & & & & & & & & & & & & & \\
\hline Transparency of metering & $\mathrm{P}$ & & & & & & & & & & & & & & \\
\hline Supervision of service & $\mathrm{P}$ & & & & & & & & & & & & & & \\
\hline Tariff structure & $\mathrm{P}$ & & & & & & & & & & & & & & \\
\hline
\end{tabular}

A, B , C .. G - companies 1,2,3 - professionals $\mathrm{O}$ - Opinion $\mathrm{P}$ - problematic.

- Establishment of metering service providers on a structured basis with respect to their definition, technical quality standards and frequency of inspection may encourage advanced meter implementation.

- Development of metering system inspection agents is feasible because the scope of this activity is aggregated to other functions to ensure its sustainable cost-effectiveness.
- Implementation of prepaid meter projects, even those operated by condominiums, establishment is not feasible because of the high cost and legal concerns involved with respect to cut-offs of water and gas, unless they are aggregated to subsidized programs.

The review of the literature and the responses of interviewees suggest that the success of implementation of advanced metering systems 
Table 5. Open codification of responses by category and group of professionals.

\begin{tabular}{|l|c|c|c|c|}
\hline Category & Group & $\begin{array}{c}\text { Do not } \\
\text { agree }\end{array}$ & $\begin{array}{c}\text { Partially } \\
\text { agree }\end{array}$ & $\begin{array}{c}\text { Totally } \\
\text { agree }\end{array}$ \\
\hline \multirow{2}{*}{$\begin{array}{l}\text { Transfer of ownership of metering } \\
\text { instruments from utilities to other players }\end{array}$} & UC & 1 & 5 & 1 \\
\cline { 2 - 5 } & OE & 0 & 5 & 2 \\
\hline \multirow{2}{*}{ Establishment of metering service providers } & UC & 2 & 3 & 1 \\
\cline { 2 - 5 } & OE & 2 & 5 & 0 \\
\hline $\begin{array}{l}\text { Development of metering system inspection } \\
\text { agents }\end{array}$ & UC & 1 & 2 & 4 \\
\cline { 2 - 5 } $\begin{array}{l}\text { Use of prepaid systems operated by } \\
\text { condominiums }\end{array}$ & OE & 0 & 1 & 6 \\
\cline { 2 - 5 } & OE & 1 & 2 & 4 \\
\hline
\end{tabular}

UC - professionals from the utility companies (total number: 7); OE - professionals from companies working in metering systems implementation (total number: 7).

depends mainly on management aspects rather than on technological ones.

The point most relevant to development and sustainability of the use of advanced metering systems is expansion of the scope of activities of the companies that provide individual metering and remote systems.

As a consequence, a management model for encouraging metering individualization through advanced metering may be developed through the actions of the players involved. This management model should encompass a definition of the scope of services provided by meter service providers and the establishment of performance requirements for service quality control.

A supervision management system is also necessary to ensure compliance with those requirements. This may be achieved through the appointment development of metering systems inspection agents. However, the sustainability of this player seems difficult to ensure owing to issues of economic scale.

Another important factor in the cost-effectiveness of introducing advanced metering, as well as its sustainability, is the transfer of ownership of gas and water meters from the utilities to other entities.

The responses obtained from both groups of professionals interviewed were consistent with the literature review regarding to the fact that regulation of monopolies is already beginning in some countries. This makes it very difficult to introduce high-impact innovations.

The establishment of meter service providers on a structured basis and the development of a proper model for primary meter ownership and control may also help to promote the convergence of the services of the utilities companies.

With respect to technological issues, simple and inexpensive options seem to be the best choice because of the small initial scale for water and gas advanced metering activities. Prepayment systems operated on a small scale are not adequate if operated by condominiums, owing to the lack of measurement transparency.

\section{CONCLUSIONS}

The proposed actions for encouraging advanced metering are summarized below. These measures are not isolated actions but rather actions that can be combined:

- Establishment of metering service providers on a structured basis compatible with current conditions;

- Development of metering system inspection agents;

- Extension of metrological and legal supervision of meters managed by gas and water utilities to meters managed by third parties (for example, 
condominiums with apartments meter service providers);

- Advanced metering technologies may be introduced without prejudicing existing ownership transfer instrument controls. In addition, utilities could reap benefits from advanced metering technologies provided by condominiums in terms of economies of scope.

The use of simple and proven technologies that do not require large-scale projects to be effective is necessary. One example is radiofrequency data transmission via the portable network (PN) widely used in the United States. Prepaid meters, even those owned and operated by condominiums, are not completely discarded as options, but the results of this study suggest that costly projects would be feasible only if they were subsidized by the government.

\section{REFERENCES}

[1] FERC-Federal Energy Regulatory Commission. "Reports on Demand Response and Advanced Metering", pp. 1-110. 2010. Date of visit: December 18, 2013. URL: http://www.ferc.gov

[2] S. Moore and D.M. Hughes. "Advanced Metering. Infrastructure: Lifeblood for Water Utilities". American Water Works Association Journal. Vol. 100, Issue 4, pp. 64-66, 68. April, 2008. ISSN: 2164-4535.

[3] D. Hec. "Introducing smart meters in Europe: The challenge of standards". $25^{\text {th }}$ World GasConference. IGU-Internacional Gas Union. Cologne. Germany. 2012.

[4] F. Mehdi, A. Fetz and M. Filippini. "Economies of scale and scope in multi-utilities". The energy journal. Vol. 29, Issue 4, pp. 123124. April, 2008. ISSN: 0360-5442. DOI: 10.5547/ISSN0195-6574-EJ-Vol29-No4-6.

[5] A. Berg "Multi-utility strategy-success or failure?". Proc. The Nordic Energy Conference. Hafslund, Norway. 2005.

[6] A. Bhure. "Regulatory challenges-The implementation of AMI." Metering International. Issue 2, pp. 56. April, 2007. ISSN: $1025-8248$.

[7] B. Reynolds. "The changing face of submetering. Sub-metering AMR takes off."
Metering International. Issue 2, pp. 20- 21. April, 2007. ISSN: 1025-8248.

[8] J. Roberts. "Multi-utilities-The way forward", pp. 59-70. December 6, 1998. Date of visit: April 14, 2010. URL: http://ieeexplore.ieee. org/xp1/freeabs_all.jsp?tp=\&arnumber $=678$ 986\&isnumber $=14936$

[9] OFGEM - Office of the Gas and Electricity Markets. "Code of practice for gas meter asset managers", pp. 1-100. September, 2005. Date of visit: February 15, 2010. URL: http://www. ofgem.gov.uk/Networks/ Techn/Metrolgy/ AssetMgmt/mamcop/Documents1/8802schememanagement boardtor.pdf

[10] M.P.C. Weijenen, J.M. Bauer, A.L. Turk and P. M. Herder. "Convergence and the working of markets". Conference on Working of Markets. Michigan State University. Department of Telecommunications. East Lansing, MI, USA. October 20, 2000.

[11] B. Mainali and S. Silveira. "Renewable energy markets in rural electrification: Country case Nepal". Energy for Sustainable Development. Vol. 16, Issue 2. June, 2012, pp. 168-178. 2012. ISSN: 0973-0826. DOI: 10.1016/j. energy.2010. 07.004.

[12] D.Barnes and J. Halpern. "Reaching the poor: designing energy subsidies to benefit those that need it". Refocus. Vol. 2, Issue 6, pp. 32-37. July, 2001. ISSN: 1471-0846. DOI: 10.1111/j.1757-1707. 2010.01088.x.

[13] K. Rijal. "Renewable energy policy options for mountain communities: experiences from China, India, Nepal and Pakistan". Renewable Energy. Vol. 16, Issues 1-4, pp. 1138-1142. January-April, 1999. ISSN: 0960-1481. DOI: 10.1016/S0960-1481(98)00444-3.

[14] D. Sharma. "Transforming rural lives through decentralized green power". Futures. Vol. 39, Issue 5, pp. 583-596, June, 2007. ISSN: 00163287. DOI:10.1016/j.futures.2006.10.008, 2007.

[15] C. Alvial-Palavicino, N. Garrido-Echeverría, G. Jiménez-Estévez, L. Reyes and R. PalmaBehnke. "A methodology for community engagement in the introduction of renewable based. Energy for Sustainable Development". Vol. 15, Issue 3, pp. 314-323. September, 2011. ISSN: 0973-0826. DOI: 10.1016/j. esd.2011.06.007. 
[16] V. Frauenhofer. "Reading meters by radio". Pipeline Gas Journal, pp. 14-18. 1986. ISSN: 0032-0188.

[17] J. Venâncio and D' Oliveira R. "Applications of the Automatic Meter Reading Techniques at the Brazilian Gas Domestic Market". International Gas Union - IGU - World Gas Conference. Nice, France. 2000.
[18] U. Flick. "Uma introdução á pesquisa qualitativa”. Bookman Companhia Editora. 2a Edição. Porto Alegre, Brazil. Vol. 1, pp. 89-109. 2007. ISBN: 978-85-363-0414-4.

[19] L. Coehen, L. Manion and K. Morrison. "Reserch methods in education". Taylor and Francis Group. London. $5^{\text {th }}$ edition. London, United Kingdom. Vol. 1, pp. 105-132. 2005. ISBN: 0-415-19541-1. 